\title{
In Memoriam Fergus Millar
}

\author{
I $935-20$ I 9
}

F ergus Millar, who died on Is July 20I9, made many substantial contributions to the study of Jewish history in the Hellenistic and Roman worlds, not least in the pages of the Journal of Jewish Studies.

Fergus, who was a very active and towering figure in the world of Roman studies over a long career, never explained in public how he came to spend so much of his working life on the history of the Jews. In the notes he left (with characteristic forethought) for the benefit of obituarists, Fergus stated that it was by chance that, a year after he took up his post in 1964 teaching Ancient History at The Queen's College, Oxford, he happened to encounter Geza Vermes, shortly after Geza's arrival in Oxford as Reader in Jewish Studies. Geza himself wrote that he considered their meeting a providential accident, but, if so, Fergus helped providence by turning up to listen to one of Geza's first lectures in Oxford. According to the preface of his classic study on The Emperor in the Roman World (1977), Fergus had already been immersed in Josephus' Jewish War and Antiquities in the late summer of I96I.

The task of revising Emil Schürer's History of the Jewish People in the Age of Jesus Christ, to which Geza recruited Fergus in 1965, lasted from 1969 to 1986. Schürer's History was a classic of nineteenth-century scholarship which was still much cited despite being hopelessly out of date. It was quite remarkable that a Roman historian at the height of his career should choose to devote himself to the selfless task of updating it. In retrospect he put his involvement in the Schürer project down to Geza's persuasive charm, but it cannot have been irrelevant that in 1959 he had married Susanna Friedmann, daughter of a Berlin cantor. It was a massive undertaking, completed with outstanding thoroughness and precision. Fergus and Geza shared equally the task for volume I (on the political history) and volume 2 (on cultural setting, political institutions and religion), although it is clear that Fergus played a

JOURNAL OF JEWISH STUDIES | VOL. LXXII NO. 2 | AUTUMN 202I | pp. 235-9 | ISSN 0022-2097| https://doi.org/IO.I8647/350I/JJs-202I | https://orcid.org/oooo-00oI-62I4-I229| COPYRIGHT (C) Oxford Centre for Hebrew and Jewish Studies, 202I. O Open access article under C C-B Y-N C-N D licence, freely available from the JJS website. 
predominant role in revising the sections which relied on detailed discussions of Greek texts and inscriptions, and by volume 3 Fergus was focused explicitly on diaspora Judaism, on which he was to write extensively in later years.

The collaboration with Geza led to the first of Fergus's major contributions to JJS. Asked to review the new English translation of Martin Hengel's magisterial Judentum und Hellenismus, he published in 1978 as a review article, which has become a classic, a substantial re-evaluation of the background to the Maccabean revolution. By this time he had left Oxford in 1976 to take up the post of Professor of Ancient History in University College London in succession to Arnaldo Momigliano. At UCL he cultivated close ties with the Department of Hebrew and Jewish Studies, studying Hebrew with Ada Rapaport-Albert, while he was working on the final volume of Schürer, and it was not accidental that his inaugural lecture in 1984 on his return to Oxford as Camden Professor of Ancient History was published in JJS - the lecture, entitled 'Empire, Community and Culture in the Roman Near East: Greeks, Syrians, Jews and Arabs', was not originally written for publication and was in effect a prospectus for his major study of The Roman Near East, eventually published in 1992. It was not entirely obvious that it belonged in a journal devoted to Jewish studies, but it was a characteristic of Fergus's studies of Jewish history that he made great efforts to ensure that Jews were understood against the background of wider cultures. In any case, he noted that 'I have got into the habit of following Geza Vermes's suggestions; and ... it seems too late to stop now.'

The same breadth of approach, using the Jewish evidence for deep insights into the wider ancient world, characterized the remarkable study of 'Hagar, Ishmael, Josephus and the Origins of Islam', published in JJS in 1993. The third volume of his collected essays, published in 2006, was entitled The Greek World, the Jews and the East and contains, among many other contributions on Jewish history, his influential study on the Jews of the Graeco-Roman diaspora between paganism and Christianity in late antiquity, which had originated in a seminar in UCL, organized by Judith Lieu, John North and Tessa Rajak, on the Jews among pagans and Christians in the Roman Empire.

After he stepped down from the Camden Chair in 2002, Fergus had an extraordinarily productive retirement in the seventeen years he was attached to the Oxford Centre for Hebrew and Jewish Studies in his shared office in 


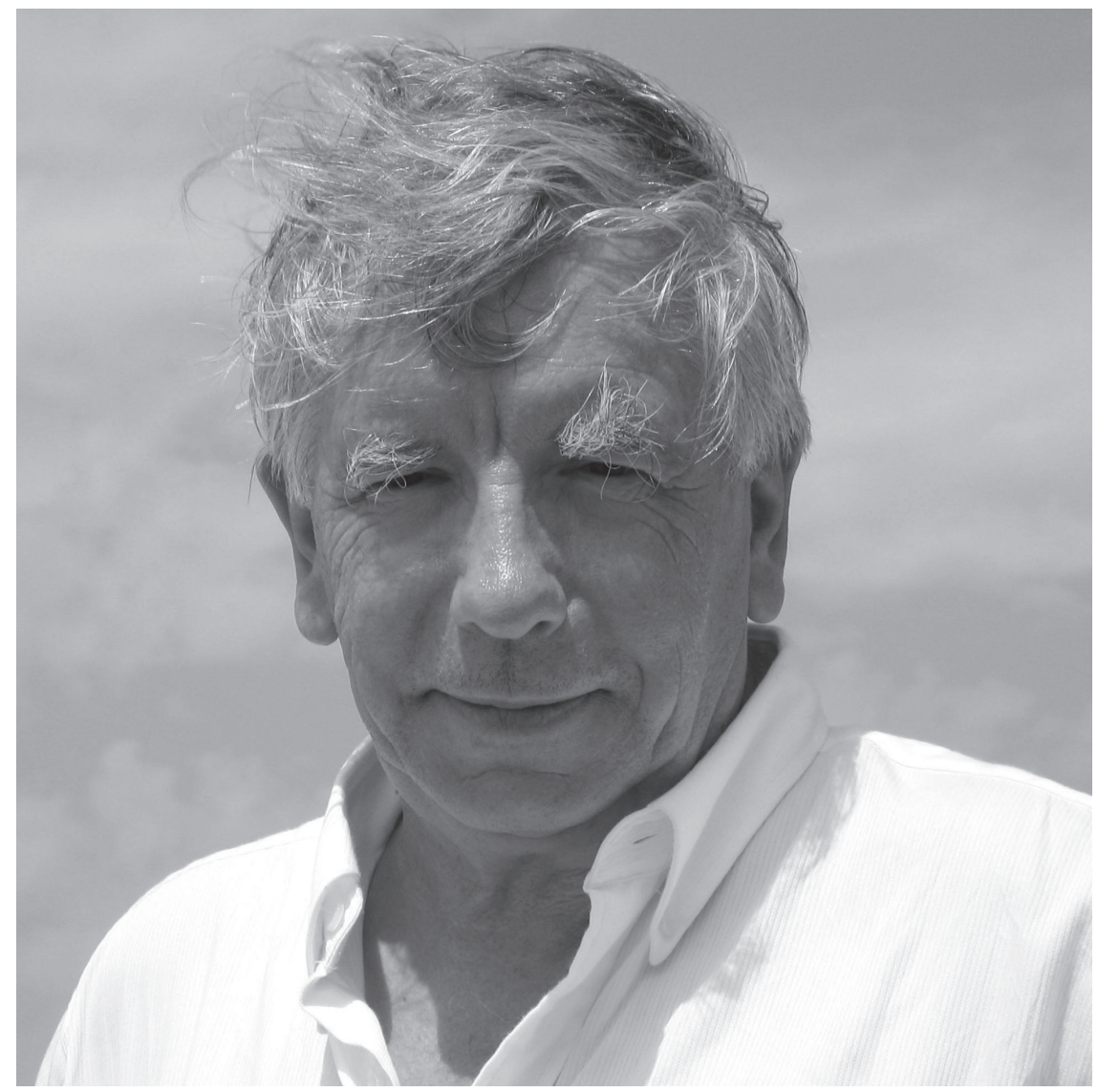

Photo: Sarah Millar

the Oriental Institute (and later in the Clarendon Institute). Moving into the field of late antiquity, about which he had previously written little, in 2003 he gave the Sather Lectures in Berkeley on 'A Greek Roman Empire: Power and Belief under Theodosius II, 408-450' (published in 2006), from which emerged his study of 'Christian Emperors, Christian Church and the Jews of the Diaspora in the Greek East (C E 379-450)', published in JJS in 2004. The publication in $200 \mathrm{I}$ of Seth Schwartz's Imperialism and Jewish Society was fortuitous for these new projects, and Fergus published a full response to Schwartz's study in JJS in 2006. The appearance in 2006 of volume IV of the Cambridge History of Judaism, of which he had reviewed the first volume critically in 1984 in the Times Literary Supplement, provided an opportunity 
for another extensive review article in JJS in 2008, characterized more enthusiastically as a series of 'supplements' to the history of 'the many worlds of the late antique diaspora' rather than a 'response' or a 'critique'.

Fergus became fascinated by the direct access to voices from the Near East in late antiquity available through the survival of ancient manuscripts in Syriac and longed for a similarly direct link to Jewish material, putting great emphasis on the value to historians of the documentary papyri from the Judaean desert and inscriptions both on stone and on mosaic, and insisting on the justification for reconstructing late-antique Jewish history from these concrete materials and the references to Jews in Christian writers writing in Syriac as well as in Greek and Latin alongside, and sometimes in preference to, later rabbinic tradition. It was typical of Fergus that he dealt with his irritation at the lack of a guide to the rabbinic texts on which he felt that he could rely as a historian of the ancient world with the same confidence he felt in using the Syriac material by co-writing, with Eyal Ben-Eliyahu and Yehudah Cohn, a Handbook of Jewish Literature from Late Antiquity, published by the British Academy in 20I2, although it cannot be said that the exercise, which laid out clearly the difficulties in using these texts for history, made him any more inclined to make use of the rabbinic material himself. On the other hand, he discovered an interest, novel for him and sparked in particular by the synagogue floor at Sepphoris, in the interpretation of the iconography of mosaics.

The essays on Jewish history in the substantial final volume of Fergus's collected articles (Empire, Church and Society in the Late Roman Near East: Greeks, Jews, Syrians and Saracens), which brought together in 2015 essays originally published between 2004 and 2014, included a robust insistence on the implausibility of divorcing the references to rabbis on inscriptions from Late Antique Palestine from the references to rabbis in the rabbinic texts and an equally robust response to the theory of a 'split' Jewish diaspora, which in his view seriously underplayed the extent to which Greek played a role in communities (including communities of Jews) in the Near East in late antiquity.

All these studies, expressed with characteristic force and an impressive lack of self-doubt, stressed the importance of understanding the Jewish evidence against the background of wider ancient society and an insistence on the significance of the Jewish material for classicists, who had ignored it for too 
long. For those of us privileged to learn from him and to work with him, his influence came as much through his personality and his style as from his scholarly output. He revelled in introducing audiences to evidence which had previously escaped scholarly attention and he could be guaranteed to ask searching questions and put forward helpful suggestions of immense value to speakers in the research seminars which he continued to attend with great constancy almost to his last days.

Very clear on his own views and values, he was open to discussion of all ideas, seeing scholarship as the product of social interaction. The large crowd of friends who came to celebrate his 84 th birthday over coffee when he knew he was already very ill was a testimony to his sociability and his success in reaching out to so many people, and he would probably have been pleased that it was his personal qualities of tolerance, generosity, humanity, integrity and courage which were emphasized in the many obituaries published in the months after his death as much as his immense contributions to historical knowledge and understanding. 